\title{
ICARDA's Rangeland Ecology and Management Research Strategy for Nontropical Dry
} Areas

\section{By Mounir Louhaichi}

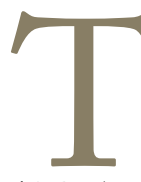

he International Center for Agricultural Research in the Dry Areas (ICARDA), established in 1977, is one of the 15 centers supported by the Consultative Group on International Agricultural Research (CGIAR), which is a strategic alliance of countries, international and regional organizations, and private foundations. The CGIAR grew out of the international response to widespread concern that many developing countries would succumb to hunger. Its main objectives are to reduce poverty and hunger, improve human health and nutrition, and enhance ecosystem resilience through high-quality international agricultural research, partnership, and leadership through generation of global public goods. The technologies and knowledge developed over the last four decades by CGIAR-supported centers and their partners have delivered significant gains in terms of reduced hunger and improved incomes for smallholder farmers across much of the developing world. They have also contributed to sustainable management and conservation of natural resources, thereby protecting millions of hectares of forest and grasslands, safeguarding biodiversity, and preventing land degradation. ${ }^{1}$ In particular, ICARDA's mission is to contribute to the improvement of livelihoods of the resource-poor in dry areas by enhancing food security and alleviating poverty through research and partnerships to achieve sustainable increases in agricultural productivity and income, while ensuring the efficient and more equitable use and conservation of natural resources. ${ }^{2}$ ICARDA has a global mandate for the improvement of barley, lentil, and faba bean and serves to improve on-farm water use efficiency, rangeland ecology and management, and small-ruminant production in the nontropical dry areas of developing countries. ICARDA meets this challenge through research, training, and dissemination of information in partnership with the national, regional, and international agricultural research and development systems. ${ }^{2}$ This paper focuses on ICARDA's research strategy for sustainable rangeland management in nontropical dry areas of developing countries. Rangelands in these areas represent by far the most widespread land use. For instance, in the Central and West Asia and North Africa (CWANA) region, they occupy more than 750 million hectares, translating to approximately $70 \%$ of the total land area. ${ }^{3,4}$ These complex landscapes and agro-ecological systems are influenced by geology and climate, as well as by current and historical management. They are the main source of livelihoods for the poorest and most marginal communities. ${ }^{5}$

Integrated range-livestock production systems have a high socioeconomic as well as cultural value due to the multiple roles these systems play as sources of subsistence, food security, income, capital reserves, and social status. ${ }^{6}$ More recently, with the increasing outcomes of global warming, there has been increasing attention to the role of rangelands as carbon sinks. ${ }^{7,8}$ However, rangeland area is decreasing as proved by measurements of the rangeland rain use efficiency coefficient; the capacity of rangelands to produce products and perform functions is declining and their biodiversity is threatened due to a combination of environmental and human-induced factors. ${ }^{9}, 10$ Worldwide, rangeland research has undergone considerable change and continues to evolve, exploring new approaches (use of satellite imagery, geographical information systems [GIS], social studies) to understand how rangelands systems function and how they might be better managed. Security of land tenure, community participation, and empowering legitimate community institutions are vital for the sustainable use of rangeland ecosystems. ${ }^{11}$

\section{Review of Past Strategy}

Rangelands are by far the most widespread land use in CWANA arid and semiarid zones, and are home to most of the region's poorest inhabitants. These are the lands that are too rocky and too sloppy, often have too-shallow soils, and 
expand under stressful environments. Rangeland issues are complex, and require a multidisciplinary approach to fully understand how to effectively manage these dynamic ecosystems. ICARDA's rangeland research began in 1985 with longterm trials conducted at ICARDA's headquarters research station. The objectives were to monitor the effects of stocking rate and phosphate fertilizer on Mediterranean grassland, measure the response of livestock production to phosphate application, assess the carrying capacity of native vegetation, and identify botanical indicators of overgrazing. ${ }^{12}$ Since then, research has progressively expanded in the arid and semiarid countries of CWANA, focusing on seed bank dynamics, community-based rangeland rehabilitation, ${ }^{13}$ palatability of Mediterranean shrubs, ${ }^{14}$ germplasm collection of native range species, ${ }^{15}$ rangeland biodiversity characterization, ${ }^{16}$ and impacts of short-term protection from grazing (resting technique), which gave remarkable results on plant cover dynamics and productivity. ${ }^{17,18}$ Research conducted within the Mashreq-Maghreb project highlighted the importance of property rights, ${ }^{19}$ policy options, ${ }^{20}$ and social and institutional aspects. ${ }^{21}$ More recently, new techniques for monitoring and assessing rangeland conditions at the local scale have been introduced to National Agricultural Research Systems (NARS) to enhance their capacity-building. ${ }^{22}$

With the severe threat of food insecurity coupled with climate change, there is a clear and urgent need for ICARDA to reinforce their rangeland research with a strategy that encompasses all stakeholders including rangeland/natural resources managers, users (pastoralists and agro-pastoralists), livestock keepers, policy makers, and planners. The present document represents ICARDA's coordinated response to the identified needs and provides a framework for NARS and other collaborators to plan effective, sustainable strategies for range management research.

\section{Research Areas}

Because of their perceived low productivity and potential, rangelands in the CWANA have often been overlooked in terms of research. As for development, millions of dollars were invested by international and national organizations during the 1960s, 1970s, and 1980s with few tangible benefits. As a result, many research and development organizations have gradually abandoned rangeland activities, and poor communities that depend on rangelands resources are becoming more and more marginalized. ${ }^{23}$ Droughts and overgrazing continue to lead to widespread land degradation and desertification. ICARDA, conscious of these challenges, is helping to reverse these trends by developing and implementing proper methods to improve rangeland management. Seven research themes have been defined as the main pillars for ICARDA's rangeland research agenda.

\section{Monitoring and Assessment}

Before engaging in any rangeland rehabilitation and management activities, there should be an inventory, assessment, and appropriate mapping of rangeland condition and utilization. To ensure that these lands are capable of providing sustainable products for future generations, their ecological condition should be monitored against specific standards. Given the dynamic nature of plant community responses to climate fluctuations (drought and wet conditions) and manmade disturbance (mainly overgrazing), there is a need for short- and long-term monitoring of rangelands. This should be part of a long-term national strategy, implemented independently of short-term projects. Indigenous knowledge of the local community (pastoralists) should be involved and consulted when trying to assess the status of rangeland condition. Their knowledge of past and current practices and disturbances is of great value when trying to understand the dynamic nature of any ecosystem. Furthermore, with advances in technology, particularly the use of GIS and remote sensing, large areas can be mapped and monitored rapidly providing that appropriate technologies are used. A new method for monitoring and assessing rangeland condition at the local scale, entitled digital vegetation charting technique (DVCT), has been developed in collaboration with the department of rangeland ecology and management at Oregon State University. ${ }^{22}$ The DVCT uses a digital camera mounted on a monopod and pointed vertically downward (Fig. 1a). Captured images are analyzed using a computerized vegetation measurement program based on the spectral reflectance of the color bands. This technique offers a good estimator of the aboveground vegetation cover which is one of the main factors for assessing rangeland health (Figs. 1b and 1c). This new technique presents several advantages over conventional sampling methods such as quadrates, which rely on human interpretation (human estimate). ${ }^{24}$ In particular, the DVCT is objective, rapid, and nondestructive; captures details; and can be repeated in time and space. ICARDA will assist NARS in the transfer and adoption of appropriate technology and necessary protocols. Moreover, it is necessary to assist governments and donors to respond to and mitigate the effects of drought with appropriate methodologies for establishing an early warning system. Design and implementation of a national drought management strategy supported by permanent institutional and technical infrastructure is required to ensure rational and effective response to the occurrence of this phenomenon. Such strategy is designed at national scale; however, it should take into account local realities and hence has to be developed to meet local needs of each area at risk.

\section{Biodiversity Characterization and Conservation} Conservation of ecosystem integrity is essential to maintaining rangeland biodiversity and ecosystem functions and processes. Overall, indigenous pastoral plant communities are highly degraded and many of the most valuable range species are on the verge of extinction. Therefore, highly grazed or browsed species still present in some plant populations are to be identified, conserved, and multiplied. Furthermore, drought- and salt-tolerant species need to be 
a
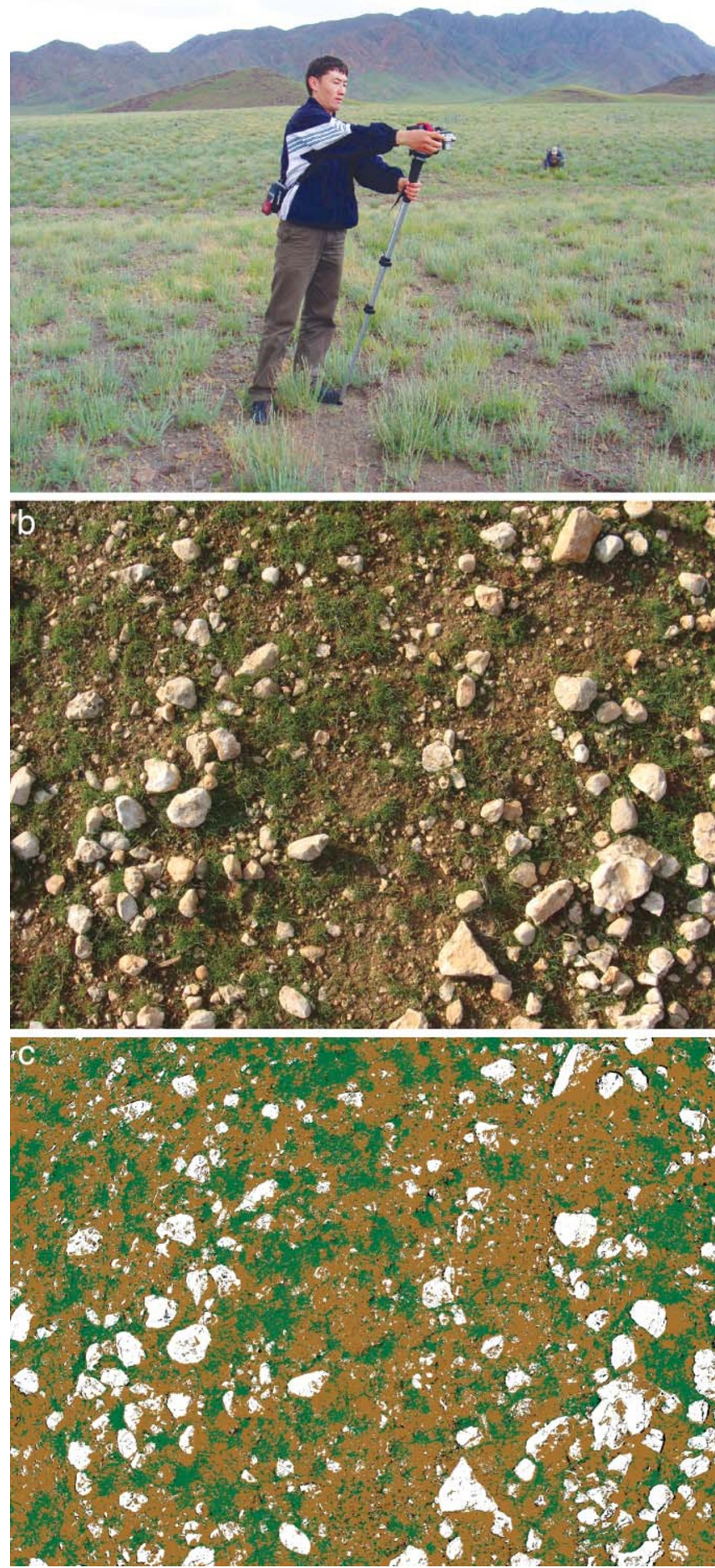

Figure 1. a, Digital vegetation charting technique being used in Central Asia rangelands to estimate percentage of green cover. $\mathbf{b}$, Original image of a pasture at Tel Hadya, Aleppo, Syria. c, Processed image indicating the following percentage of cover: vegetation (green) 25\%, bare ground (brown) 55\%, and rocks (white) 20\%.

identified for the significant areas that are prone to low rainfall and salinity. ${ }^{25}$ ICARDA will also continue its efforts to help establish and maintain field gene banks (Fig. 2a) and reference herbaria. Newly identified species will be fully characterized. Such efforts will lead to the identification of potential species with good establishment and growth vigor that could be used for rangeland rehabilitation (Fig. 2b). Furthermore, range seed production is poorly developed and there is a need to develop new seed production techniques. Priority will be given to the following:

- Key native rangeland species that are stress-tolerant to drought, cold, salt, and grazing such as the following:

- Shrubs: Salsola vermiculata, Periploca laevigata, Rhus tripartite, Retama retam, Calligonum species, Atriplex species

- Grasses: Pennisetum ciliare, Cymbopogon schoenanthus, Panicum turgidum, Stipa lagascae, Lasiurus hirsutus, Poa bulbosa, Dactylis glomerata subsp. hispanica

- Legumes: Hedysarum species, Anthyllis vulneraria, Medicago arborea, Butimenaria butiminosa, Colutea istria, Coronilla valentina subsp. glauca, Onobrychis ptolemaica, Argyrolobium

- Ethno-medicinal species (e.g., Artemisia herba-alba, Rosmarinus, Thymus, Teucrium polium)

- Underutilized and multipurpose species (e.g., Ziziphus, Pistacia atlantica, Crataegus azarolus).

Most of the proposed interventions will aid in the conservation of the rich biodiversity, in particular of the pastoral species germplasm that characterizes the region, and consequently can have positive impacts in conserving animal diversity.

\section{Rehabilitation Potential and Methods}

The ongoing development of more efficient techniques in terms of success rate and cost for rangeland enrichment using herbaceous annual and perennial species, shrubs, and trees, will continue. Techniques that have great potential but need fine-tuning are rest, soil surface preparation (scarification, pitting, etc.), direct seeding, and seed treatments (Fig. 2c). Furthermore, some research will focus on identifying native and introduced species to suit different agro-ecological situations. ${ }^{26}$ Agroforestry, particularly the integration of tree and shrub planting within private farming operations, results in multiple benefits including the production of good quality feed for livestock.

Water is a critical resource in arid and semiarid rangelands, but is often wasted or allowed to erode the landscape. Simple, cost-effective water-harvesting techniques that can be readily adopted by pastoral and agro-pastoral communities will be further developed, tested, and adapted to diverse rangeland areas and human livelihood conditions.

\section{Grazing Management}

For centuries the nomadic pastoral system was the dominant land use of the arid and semiarid areas across the whole CWANA region. The basic management problem for most pastoralists is that there is rarely enough grazing land and water at one location to enable the pastoral community and 

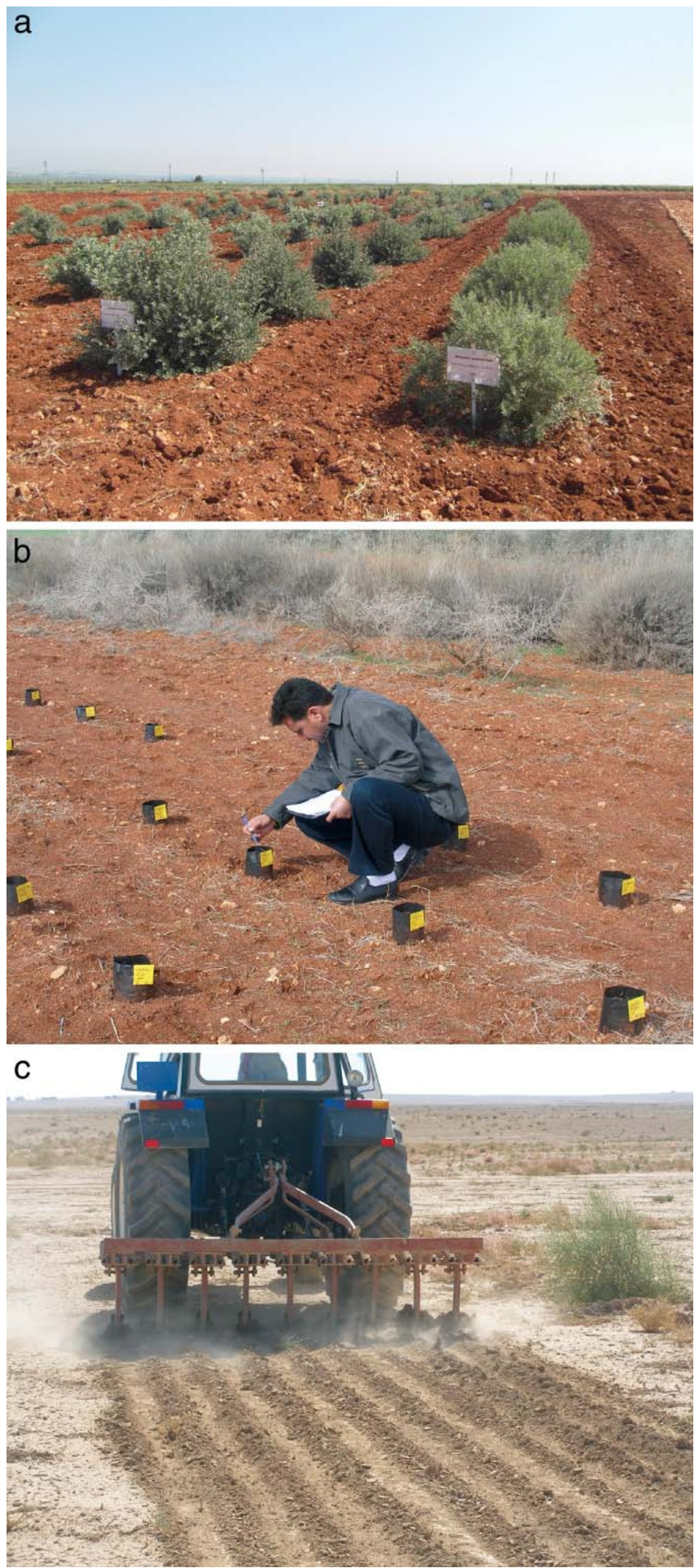

Figure 2. a, Pastoretum or field gene bank for conservation of pastoral species. b, Seed germination and establishment trials under field conditions. c, Land scarification to break the crusted surface layer.

their livestock to stay year-round in the same place. Therefore, in the past they adopted mobility to meet their livestock feeding requirements. This system is disappearing in most parts of the region as a result of changes such as tractor and truck availability, new wells in remote areas, water carted to remote places, subsidized feed, and barley cropping expanding onto rangelands, and also including recurrent drought, failure to control stock numbers in the pastoral areas, and major shifts in attitudes of pastoralists reflected in increasing interest in educating their children and benefiting from social services. These factors have resulted in increased pressure on rangeland vegetation leading to widespread rangeland degradation. Given this reality ICARDA intends to work on alleviating the pressure on these natural resources via proper grazing management. In particular, livestock grazing patterns are a key management tool that can be manipulated to enhance not only natural vegetation productivity, but also other rangeland resources such as soil and water. Understanding traditional and current livestock mobility patterns will allow us to explore new avenues for the sustainable use of rangelands and to develop grazing patterns with pastoral communities with sufficient flexibility in when and how rangelands are used. For instance, watering points are often sites of rangeland degradation and more ecologically friendly methods for watering livestock are required, for example by offering to adjust their spatial distribution within tribal grazing territories. Sustainable grazing management requires in-depth knowledge of animal behavior (Fig. 3) ${ }^{27}$ and competition and complementarily among animal species. Therefore, carrying capacity and choice of animal species for each range type (space and time) are all factors that influence the long-term use of rangelands.

\section{Institutional Arrangements and Policy Options}

A general problem in the region is the lack of or poor communication and coordination between the various institutions servicing and supporting pastoralists in general and communal rangelands in particular. The objectives of the pastoralists and their initial participation were rarely considered at the inception of the projects. As a result the majority of the past efforts directed to the development of pastoral areas were sectoral (mostly technical with no consideration for social aspects: tribal rules, land tenures, etc.). Nowadays, community participation cannot be ignored any longer as

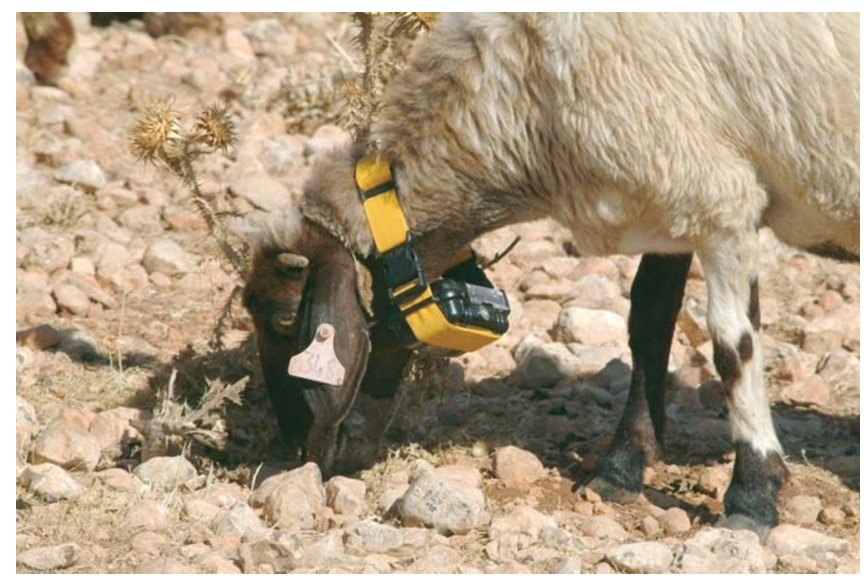

Figure 3. Awassi sheep wearing global positioning system collars to monitor their diurnal activity. 
decentralization and local empowerment are gaining momentum. Land tenure remains the most important issue involved in the management and restoration of degraded, extensive communal rangelands. Developments that improve the productivity and/or sustainability of rangelands require that a set of policies be in place that will assure pastoral communities that they will benefit from the improvements made. ${ }^{28}$ Ownership, whether in legal terms or in practice, needs to be cultivated and respected so that pastoralists will become guardians of their resource base, thus encouraging long-term sustainable management. Further research on land tenure arrangements is required to encourage best management practices throughout the rangelands, regardless of tenure provisions. Pastoral communities and governments need to clearly identify the rights and responsibilities of all rangeland managers and users to ensure those with the right to manage land are aware of their management responsibilities. Without clear identification of roles and responsibilities there is a risk that potentially useful interventions may not be pursued. Enabling policies and local institutional innovation must be developed that ensure participatory range management, in which pastoral communities and other stakeholders partner with government agencies in designing, implementing, and monitoring rangeland resource management and development plans.

\section{Ecosystem Services}

Rangeland resources have been perceived by the public and many professionals in terms of their ability to supply forage for livestock. There should be an increased research and development emphasis on managing rangelands to produce sustainable alternative products and ecosystem services such as ecotourism, organic animal products, etc. The methodology will adopt an integrated-development research model that uses community-based approaches to identify potential activities related to natural resources and sustainable intensification, diversification, and market opportunities. Rangelands could also be valued for their intrinsic beauty, as well as the commodities they may produce. Besides the traditional notions of ecosystem goods such as food, forage, timber, pharmaceuticals, and fuels, emerging fields include processes and services vital to human life. In fact, rangelands play important roles in conservation of genetic resources and contribute to soil and watershed protection. More recently, with the increasing threats of global warming, attention has been given to the role of rangelands as carbon sinks. An initial task will be to carefully identify and quantify each commodity and then to demonstrate the feasibility of society having to pay for such services ${ }^{29}$ given that they do not conflict with the ethical, social, and traditional customs of the local community.

\section{Capacity Development and Knowledge Networks} Human resources in the national programs are the cornerstone for success for rangeland development, so it is essential to continue strengthening and upgrading the capacity of the

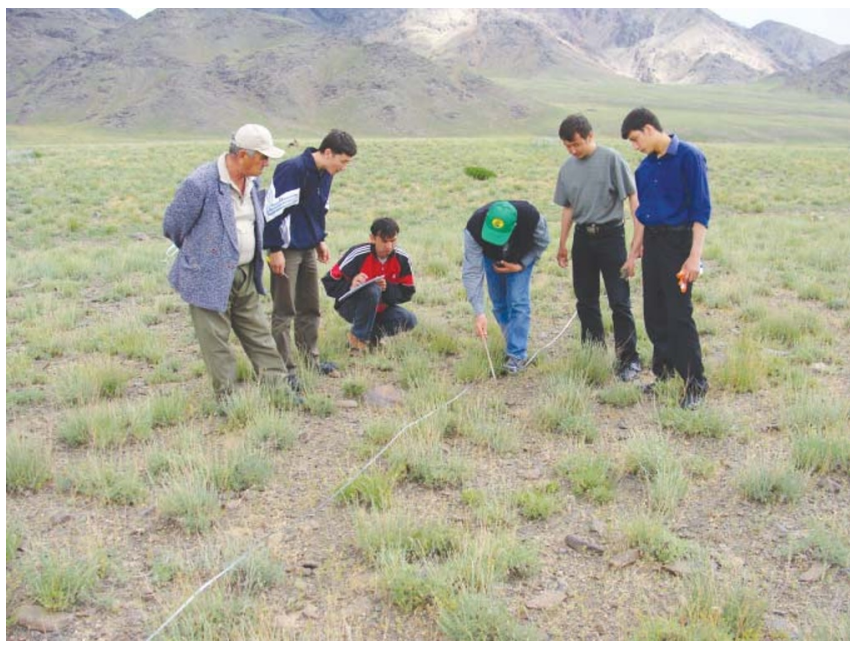

Figure 4. The International Center for Agricultural Research in the Dry Areas' rangeland scientist demonstrating the line-intercept method to young scientists in Khujand, Tajikistan.

individuals and institutions involved in rangelands research for development. Appropriate training and education should be undertaken, especially in planning and evaluation, and strengthening ties with the national programs and policy makers should remain a top priority (Fig. 4).

The training program should include several measures: 1) support for research and technology transfer, 2) policy formulation, 3) exchange of experience, information, and data, 4) collection of native species and exchange of germplasm, 5) sustainable management of common resources, and most important, 6) training and capacity development, as the number of expert rangeland scientists has been declining. ${ }^{23}$

In fact, with the newly established consortium, which unites the international agricultural research centers supported by the CGIAR and provides a single contact point for donors, collaboration between the centers and other partners will be strengthened. Fifteen CGIAR research programs (CRP), which entail a large range of partnerships, have been identified. ICARDA is leading CRP 1.1, targeting integrated agricultural production systems for dry areas in collaboration with several sister centers including the International Crops Research Institute for the Semiarid Tropics, Bioversity International, the International Livestock Research Institute, and others. In parallel, ICARDA is taking an active role working side by side with worldwide leading research institutions to promote science such as the World Overview of Conservation Approaches and Technologies, which is a global network of soil and water conservation specialists, contributing to sustainable land management. Furthermore, ICARDA is contributing to the growing data networks. ICARDA's efforts will become visible once the newly developed "geonetwork" site is officially inaugurated in 2011.

\section{Acknowledgments}

The author thanks several anonymous reviewers for their invaluable reading and corrections that helped improve this 
manuscript. Special thanks go to Dr Gustave Gintzburger (program leader and Pasture, Forage and LivestockRange specialist at ICARDA, 1992-99) and Dr Barbara Rischkowsky (Senior Livestock Production System at ICARDA) for their critical review and comments of this article and their well-defined priority research areas. I am also grateful to Mr Mohamed Mirreh (former Food and Agriculture Organization of the United Nations Regional Near East Range Management Officer) for his in-depth knowledge of the rangeland constraints and opportunities in the region. This work was supported by the ICARDA, Aleppo, Syria.

\section{References}

1. Consultative Group on International Agricultural Research. 2011. CGIAR home page. Available at: http:// www.cgiar.org/. Accessed 6 February 2011.

2. [ICARDA] International Center for Agricultural Research in the Dry Areas. 2007. Improving livelihoods in the dry areas. Strategic plans 2007-2016. Aleppo, Syria: ICARDA. 52 p.

3. Gintzburger, G., H. N. Le Houérou, and K. N. Toderich. 2005. The steppes of Middle Asia: post-1991 agricultural and rangeland adjustment. Arid Land Research and Management. 19(3):215-239.

4. Gintzburger, G., H. N. Le Houérou, and S. Saïdi. 2006. Near East-West Asia arid and semi-arid rangelands. Sécheresse 17(1-2):152-68.

5. Reynolds, J. F., and D. M. Stafford Smith. 2002. Global desertification: do humans cause deserts? Berlin: Dahlem Workshop Report 88, Dahlem University Press. 437 p.

6. Reynolds, J. F., D. M. Stafford-Smith, E. F. Lambin, B. L. Turner II, M. Mortimore, S. P. J. Batterbury, T. E. Downing, H. Dowlatabadi, R. J. Fernández, J. E. Herrick, E. Huber-Sannwald, H. Jiang, R. Leemans, T. Lynam, F. T. Maestre, M. Ayarza, and B. Walker. 2007. Global desertification: building a science for dryland development. Science 316(11):847-851.

7. Nemani, R. R., C. D. Keeking, H. Hashimoto, W. M. Jolly, S. C. Piper, C. J. Tucker, R. B. Myneni, and S. W. Running. 2003. Climate-driven increases in global terrestrial net primary production from 1982 to 1999. Science 300:1560-1563.

8. Zhao, M., And S. W. Running. 2010. Drought-induced reduction in global terrestrial net primary production from 2000 through 2009. Science 329:940-943.

9. Herrmann, S. M., A. Anyamba, and C. J. Tucker. 2005. Recent trends in vegetation dynamics in the African Sahel and their relationship to climate. Global Environmental Change Human and Policy Dimensions 15:394-404.

10. Perevolotsky, A., and N. G. Seligman. 1998. Role of grazing in Mediterranean rangelands ecosystems. BioScience 48:1007-1017.

11. Tiedeman, A. J., C. Dutilly-Diane, N. Batikha, F. Ghassali, E. Khoudary, G. Arab, C. Saint-Macary, and M. Louhaichi. 2006. Rangeland degradation related to social and ecological characteristics in the Syrian steppe. The 8th International Conference on Development of Drylands, theme 3: Desert communities and socio-economic studies; 25-28 February 2006; Beijing, China. Aleppo, Syria: ICARDA. 849 p.

12. Osman, A. E., M. Pagnotta, L. Russi, P. S. Cocks, and M. Falcinelli. 1990. The role of legumes in improving marginal lands in the role of legumes in the farming systems of the Mediterranean areas In: A. E. Osman, M. H. Ibrahim, and M. A. Jones [EDs.]. Developments in plant and soil sciences 38. Dordrecht, Netherlands: Kluwer Academic Publishers. 310 p.

13. Ghassali, F., P. S. Cocks, A. E. Osman, G. Gintzburger, S. Christiansen, A. Semaan, and M. Leybourne. 1999. Rehabilitation of degraded grasslands in north Syria: use of farmer participatory research to encourage the sowing of annual pasture legumes. Journal of Experimental Agriculture 35:489-506.

14. Nefzadui, A., H. Ben Salem, H. Ferchichi, and H. Abdouli. 2000. Palatability of Mediterranean shrubs: comparison between browsing and cafeteria techniques using goats. In: G. Gintzburger, M. Bounejmate, and A. Nefzaoui [EDs.]. Fodder shrub development in arid and semi-arid zones. Proceedings of the Workshop on Native and Exotic Fodder Shrubs in Arid and Semi-arid Zones; 27 October-2 November 1996; Hammamet, Tunisia. Aleppo, Syria: ICARDA. p. 524-530.

15. Robertson, L. D., M. Bounejmate, M. Acherkouk, A. Bechari, M. El Koudrim, and A. MaAtougui. 1997. Collecting range species in Morocco. Dryland Pasture, Forage, and Range Network News (ICARDA publication) 14:8-9.

16. Gintzburger, G., K. N. Toderich, B. K. Mardonov, and M. M. Mahmudov. 2003. Rangelands of the arid and semi-arid zones in Uzbekistan. JOUVE, Paris, France: CIRAD-ICARDA. 426 p.

17. Louhaichi, M., A. K. Salkini, and S. L. Petersen. 2009. The effect of small ruminant grazing on the plant community characteristics of semi-arid Mediterranean ecosystems. International Journal of Agriculture and Biology 11:681-689.

18. Tastad, A., A. W. Jasra, A. K. Salkini, N. Battikha, and M. Lounaichi. 2010. Ecological status of protected and unprotected rangelands in Syria: monitoring the impact of grazing on rangeland vegetation dynamics in three climatological zones. Journal of Agricultural Sciences 47(2):89-98.

19. Ngaido, T., A. Nefzaoui, F. Awawdeh, M. Elloumi, and K. Aвu Soui. 2007. Range management options and transaction costs amongst pastoral households in West Asia and North Africa. In: A. El-Beltagy, M.C. Saxena, and Tao Wang [EDs.]. Humans and nature - working together for sustainable development of drylands. Proceedings of the Eighth International Conference on Development of Drylands; 25-28 February 2006, Beijing, China. Aleppo, Syria: ICARDA. p. 682-694.

20. Alary, V., and M. El-Mourid. 2005. Les politiques alimentaires au Maghreb et leurs conséquences sur les societes agropastorales. Revue Tiers Monde 36(184):785-810.

21. Dutilly-Diane, C. 2006. Gestion collective des parcours en zone agro-pastorale: le cas de Ait Ammar (Maroc). Afrique Comtemporaine 219(3):103-117.

22. Louhaichi, M., M. D. Johnson, A. L. Woerz, A. W. Jasra, And D. E. Johnson. 2010. Digital charting technique for monitoring rangeland vegetation cover at local scale. International Journal of Agriculture and Biology 12:406-410.

23. Gintzburger, G. 1999. A rangeland strategy for ICARDA: notes and comments. Aleppo, Syria: ICARDA. 32 p.

24. Hill, D., M. Fasham, G. Tucker, M. Shewry, and P. Shaw. 2005. Handbook of biodiversity methods: survey, evaluation and monitoring. Cambridge, United Kingdom: Cambridge University Press. 388 p.

25. Lounaichi, M., and A. Tastad. 2010. The Syrian steppe: past trends, current status and future priorities. Rangelands $32(2): 2-7$. 
26. Le Houḱrou, H. N. 1999. Use of fodder trees and shrubs (trubs) in the arid and semi-arid zones of West Asia and North Africa: history and perspectives. In: G. Gintzburger, M. Bounejmate, and A. Nefzaoui [EDs.] Fodder shrubs development in arid and semi-arid zones. Proceedings of a Workshop; 27 October-2 November 1996, Hammamet, Tunisia. Aleppo, Syria: ICARDA. p. 9-53.

27. Louhaichi, M., M. D. Johnson, And D. E. Johnson. 2010. Inference of ruminant's activity using GPS-based animal tracking technologies. Annual Conference on Tropical and Subtropical Agricultural and Natural Resource Management; 14-16 September 2010, Zurich, Switzerland. Witzenhausen, Germany: German Institute for Agriculture in the Tropics and Subtropics. $444 \mathrm{p}$.

28. Nefzaoui, A., M. El Mourid, V. Alary, T. Ngaido, and K. El Harizi. 2007. Empowering rural communities for better management of desert collective rangelands-from concept to implementation. In: A. El-Beltagy, M. C. Saxena, and Tao Wang [EDs.]. Humans and nature-working together for sustainable development of drylands. Proceedings of the Eighth International Conference on Development of Drylands; 25-28 February 2006, Beijing, China. Aleppo, Syria: ICARDA. p. 620-632.

29. Farber, S. C., R. Costanza, and M. A. Wilson. 2002. Economic and ecological concepts for valuing ecosystem services. Ecological Economics 41:375-392.

Author is Senior Rangeland Scientist, International Center for Agricultural Research in Dry Areas, PO Box 5466, Aleppo, Syria, M.Louhaichi@cgiar.org. 